\title{
Michał Passon
}

Uniwersytet Jagielloński

passon.michal@gmail.com

\section{Możliwość zrzeczenia się prawa do wniesienia odwołania w Kodeksie postępowania administracyjnego w świetle Konstytucji RP}

\author{
Waiving possibility to rescind administrative decision \\ from the constitutional perspective
}

\section{STRESZCZENIE}

Przedmiotem artykułu jest instytucja zrzeczenia się prawa do wniesienia odwołania od uzyskanej decyzji, która została wprowadzona do kodeksu postępowania administracyjnego w 2017 roku. Regulacja ta została wprowadzona ze względu na szybkość i ekonomię postępowania. Budzi ona jednak wątpliwości nie tylko z perspektywy dorobku administracyjno-prawnego i wypracowanej przezeń swoistej koncepcji publicznych praw podmiotowych, ale także z punktu widzenia podstawowych praw człowieka i obywatela, jakimi są prawo do zaskarżania orzeczeń i decyzji czy prawo do sądu. Konstytucyjny aspekt tego przepisu oraz jego wpływ na sferę praw i wolności jednostki nie został w pełni dostrzeżony przez ustawodawcę, ani - przynajmniej do tej pory - przez doktrynę, dlatego warto się zastanowić nad jego bliższą charakterystyką - z tego też względu, artykuł będzie obejmować próbę spojrzenia na wspomnianą instytucję właśnie z tej perspektywy.

Słowa kluczowe: zrzeczenie się, decyzja, odwołanie, nowelizacja k.p.a., publiczne prawa podmiotowe, konstytucja, prawo do sądu,

\section{WSTĘP}

Nowelizacją z dnia 7 kwietnia 2016 roku ustawodawca wprowadził do Kodeksu postępowania administracyjnego ${ }^{1}$ możliwość zrzeczenia się prawa do wniesienia odwołania. W uzasadnieniu projektu wskazuje się, że zaproponowana instytucja

1 Ustawa z dnia 14 czerwca 1960 r. Kodeks postępowania administracyjnego (Dz.U. $1960 \mathrm{nr}$ 30 poz. 168). 
ma prowadzić do skrócenia czasu trwania postępowania i realizacji tzw. „ekonomii procesowej”', a także idea przyświecająca wskazanej zmianie zdaje się dobrze korespondować z zasadą szybkości postępowania z art. 12 k.p.a. Wspomniany przepis jest wprawdzie adresowany do organów administracji publicznej, jednakże można uznać go za ogólną zasadę (nie tylko o charakterze dyrektywalnym) kodeksu postępowania administracyjnego - stronom bowiem również zależy na szybkości rozstrzygnięcia ich sprawy. Tak więc ratio legis omawianej zmiany jest spowodowanie, aby postępowanie trwało szybciej, a także to, aby przeciwdziałać i zapobiegać stanom potencjalnej przewlekłości (bezczynności) postępowań. Nie ulega wątpliwości, że konsekwencją wprowadzonej zmiany może być pozytywne przyczynienie się w odbiorze społecznym do pogłębiania zaufania w stosunku do organów władzy publicznej ${ }^{3}$. In abstracto należy przyjąć, że każda regulacja prawna mająca być realizacją zasady ekonomii procesowej zasługuje na aprobatę - oczywiście przy założeniu, że nie narusza ona uprawnień i interesów stron w postępowaniu. Kwestia ewentualnego naruszenia praw stron poprzez możliwość zrzeczenia się odwołania zdaje się być kwestią otwartą (zwłaszcza z perspektywy art. 78 ust.1 Konstytucji ${ }^{4}$ ), jednakże zanim do niej przejdę, konieczna będzie analiza poszczególnych przepisów zawartych w Konstytucji jak kodeksie postępowania administracyjnego dotyczących zarówno odwołania, a dopiero w następnej kolejności możliwości zrzeczenia się go. Wniosek taki wydaje się jak najbardziej zasadny na tle znowelizowanej wersji kodeksu postępowania administracyjnego. Ustawodawca bowiem umieścił prawo do zrzeczenia się w art. 127a, wiążąc tę kwestię z prawem do wniesienia odwołania od wydanej decyzji usytuowanym w art. 127 k.p.a., a nie w odrębnym artykule. Wykładnia systemowa jak i intencje prawodawcy zdają się wskazywać, że przepisy te należy analizować w związku ze sobą, a nie w abstrakcyjnej próżni.

\section{PRAWO DO WNIESIENIA ODWOŁANIA W KONSTYTUCJI}

Prawo do wniesienia odwołania usytuowane w k.p.a. jest uszczegółowieniem możliwości zaskarżania decyzji i orzeczeń, które przewiduje ustawa zasadnicza w treści art. 78 ust.1. Trybunał Konstytucyjny zaznaczył, że przepis ten ma istotne

2 Uzasadnienie do rządowego projektu ustawy o zmianie ustawy - Kodeks postępowania administracyjnego oraz niektórych innych ustaw, str. 56-58 (Druk nr 1183) (dostęp: 01.12.2017) http:// orka.sejm.gov.pl/Druki8ka.nsf/0/F3388D1AB00B1313C125809D004C3C8E/\%24File/1183.pdf.

3 Idea ta zdaje się odzwierciadlać realizację zasady z art. 8 k.p.a.

4 Konstytucja Rzeczypospolitej Polskiej z dnia 2 kwietnia 1997 r. uchwalona przez Zgromadzenie Narodowe w dniu 2 kwietnia 1997 r., przyjęta przez Naród w referendum konstytucyjnym w dniu 25 maja 1997 r., podpisana przez Prezydenta Rzeczypospolitej Polskiej w dniu 16 lipca 1997 r. (Dz.U. $1997 \mathrm{nr} 78$ poz. 483 ). 
znaczenie i jest gwarancją realizacji zasady sprawiedliwości proceduralnej ${ }^{5}$. Przepis ten jest nie tylko komponentą prawa do sądu z art. 45 ust. 1 Konstytucji, ale ma również charakter autonomiczny ${ }^{6}$ - wyraża bowiem konstytucyjne prawo podmiotowe do zaskarżenia wydanej uprzednio decyzji lub orzeczenia. ${ }^{7}$ Art. 78 ust.1 Konstytucji dopuszcza możliwość zaskarżenia nie tylko orzeczeń, ale także decyzji, które zostały wydane w pierwszej instancji. Przyjmuje się, że pojęcia „orzeczeń” $\mathrm{i}$, decyzji” mają charakter autonomiczny w stosunku do form rozstrzygnięć, które występują w postępowaniach sądowych oraz pozasądowych. ${ }^{8}$ Gdyby prawodawca nie uznał za konieczne wyróżniać także decyzji, to poprzestałby na wskazaniu tylko i wyłącznie orzeczeń. Nie można zatem ograniczać zakresu zastosowania tego przepisu tylko do postępowania sądowego. ${ }^{9}$ Intencją ustrojodawcy było więc przyznanie uniwersalnej możliwości zaskarżania decyzji o tak szerokim zakresie znaczeniowym, aby strony poszczególnych postępowań mogły skorzystać z takiego uprawnienia w stopniu jak najszerszym - stąd też użycie ogólnego określenia „zaskarżenia”. ${ }^{10}$ Powyższa instytucja znalazła się podrozdziale o nazwie „środki ochrony wolności i praw" - wykładnia systemowa zdaje się potwierdzać nie tylko powyższy argument ale także podkreślać jak duże znaczenie ustrojodawca przypisuje możliwości zaskarżania orzeczeń bądź decyzji w wykonywaniu swoich wolności i praw.

Warto wspomnieć, że wprawdzie art. 176 Konstytucji wprowadza obowiązek dwuinstancyjności postępowania tylko w stosunku do postępowań sądowych, a więc nie dotyczy to sytuacji, gdy mamy do czynienia z postępowaniami administracyjnymi. Jednakże sądzę, że chęć stworzenia postępowań administracyjnych o więcej niż jednej instancji zdaje się sygnalizować ustrojodawca w treści art. 78 Konstytucji. Trudno bowiem myśleć w kontekście odwołania, które nie jest rozpatrywane przez organ wyższej instancji (choć jest to możliwe) - dlatego też w momencie wniesienia odwołania zostaje ,uruchomione rozpoznanie sprawy

\footnotetext{
5 Wyrok TK z dnia 14 czerwca 2006 r., sygn. K 53/05, OTK ZU nr 6/A/2006, poz. 66.

6 L. Garlicki i K. Wojtyczek [w:] Konstytucja Rzeczypospolitej Polskiej. Komentarz do art. 30-86, t. 2, str. 876-877, Warszawa 2016.

7 Tamże oraz J. Boć (red.), Konstytucje Rzeczypospolitej oraz komentarz do konstytucji z 1997 roku, str. 140, Wrocław 1998 oraz Z. Kmieciak, Instancyjność postęowania administracyjnego w świetle Konstytucji RP, „Państwo i Prawo” 2012, nr 5, s. 6 http://www.lex.pl/c/document_library/ get_file?uuid=08a5ab43-419d-4d93-a4a9-227bd1a05469\&groupId=2221015 (dostęp: 27.11.2017); Tenże, Odwołania w postępowaniu administracyjnym, str. 13 Warszawa 2011.

8 M. Safjan, L. Bosek (red.), Konstytucja RP. Tom I. Komentarz do art. 1-86, komentarz do art. 78, str. 1794-1796, Warszawa 2016. wyd. 1; J. Boć (red.), Konstytucje Rzeczypospolitej oraz komentarz do konstytucji z 1997 roku, Wrocław 1998.

9 W. Skrzydło, Konstytucja Rzeczypospolitej Polskiej. Komentarz, Komentarz do art. 78, str. 92, Zakamycze 2000.

${ }_{10}$ Wyrok TK z dnia 16 listopada 1999 r., sygn. SK 11/90, OTK ZU 7/1999, poz. 158
} 
w administracyjnym toku instancji"'11. Przy czym, jak wyżej zaznaczyłem, nie jest konieczne, aby odwołanie zostało rozpatrzone przez inny organ (organ II instancji) - de lege lata dopuszczalne są bowiem odstępstwa od zasady, w myśl której środki zaskarżenia mają charakter dewolutywny ${ }^{12}$.

Art. 78 ust. 2 z kolei przewiduje, że tryb zaskarżania określa ustawa. Zatem kwestie bardziej szczegółowe ustrojodawca pozostawił w gestii ustawy. Dlatego też zadaniem ustawodawcy będzie zapewnienie poszczególnych gwarancji, które pozostaną w zgodzie z regulacją konstytucyjną. Nie ulega wątpliwości, że przewidziane w ustawie rozwiązania (będące wyjątkami od powyższej zasady) muszą mieć charakter konkretny, wyraźny i nie mogą być domniemywane czy interpretowane rozszerzająco (exceptiones non sunt extendendae).

\section{PRAWO DO ODWOŁANIA W KODEKSIE POSTĘPOWANIA ADMINISTRACYJNEGO}

Prawo do wniesienia odwołania umiejscowione w art. 127 § 1 k.p.a. jest związane z art. 15 k.p.a., który stanowi, że postępowanie administracyjne jest dwuinstancyjne, chyba że ustawa zastrzega inaczej. Dwuinstancyjność w oczywisty sposób wpływa na uprawnienia strony do rozpatrzenia jej sprawy na podstawie i w granicach prawa w sposób merytoryczny przez uprawniony do tego organ administracji publicznej wyposażony w odpowiednią kompetencję ${ }^{13}$.

\section{A)ZAKRES PODMIOTOWY}

Zgodnie z brzmieniem art. 127 § 1 k.p.a. - prawo do wniesienia odwołania przysługuje stronie. W tym miejscu ustawodawca odsyła nas do treści art. 28 i 29 k.p.a., w którym, poprzez definicję legalną, wskazuje on, komu w postępowaniu administracyjny przysługuje przymiot strony. W tym miejscu warto wskazać, że uczestnicy postępowania występujący na prawach strony, de lege lata nie są stronami w toczącym się postępowaniu - ich uczestnictwo nie jest oparte na kryterium interesu prawnego (obowiązku) i występują one niezależnie od strony. ${ }^{14} \mathrm{~W}$ orzecznictwie oraz doktrynie prezentowane są dwie koncepcje strony - obiektywna oraz

11 Z. Kmieciak [w:] Reforma prawa o postępowaniu administracyjnym, str. 176 i n., Warszawa, czerwiec 2016, http://www.nsa.gov.pl/wydarzenia-wizyty-konferencje/raport-ekspercki-nt-reforma -prawa-o-postepowaniu-administracyjnym,news,24,313.php (dostęp: 07.12.2017) oraz argumenty tam przytoczone.

12 Wyrok TK z dnia 15 grudnia 2008, sygn. P 57/07 OTK-A 2008, nr 10, poz. 178.

13 Rozumianą nie tylko jako uprawnienia, ale również jako obowiązek działania dla organów administracji publicznej - patrz. J. Zimmermann, Prawo administracyjne, str. 142, Warszawa 2014, wyd. 6.

14 T. Woś [w:] T. Woś (red.), Postępowanie administracyjne, str. 207, wyd. 3. 
subiektywna. Pierwsza z nich charakteryzuje się tym, że przed wszczęciem postępowania dochodzi do weryfikacji interesu prawnego lub obowiązku potencjalnej strony przez organ administracji publicznej i dopiero po pozytywnej weryfikacji uzyskuje się status strony. Druga z kolei charakteryzuje się tym, że stroną jest każdy, kto jest subiektywnie przekonany, że postępowanie dotyczy jego interesu prawnego. ${ }^{15}$ Wydaje się, że mimo sporu, przeważającą koncepcją jest koncepcja obiektywna i do niej też bym się przychylał - nie można bowiem jedynie na podstawie własnego przekonania posiadać interes prawny, albowiem interes prawny jest kategorią, która jest obiektywnie weryfikowalna - może on istnieć albo nie, a zatem tertium non datur. Charakterystyka interesu prawnego zdaje się podważać zasadność koncepcji subiektywnej na tle art. 28 k.p.a. (nawet jeśli jej literalne brzmienie może sugerować taki wniosek), przy czym orzecznictwo zdaje się również przychylać do tego stanowiska i kłaść większy nacisk na kwestie obiektywne ${ }^{16}$.

\section{B) ZAKRES PRZEDMIOTOWY ORAZ KWESTIA PUBLICZNYCH PRAWN PODMIOTOYCH}

Odwołanie przysługuje od wydanego rozstrzygnięcia w formie decyzji administracyjnej - o czym expressis verbis stanowi treść art. 127 k.p.a. Owo uprawnienie przysługuje od decyzji, która zgodnie z zapatrywaniami doktryny prawa administracyjnego należy rozumieć jako: ,, władcze, jednostronne oświadczenie woli organu administracji publicznej, skierowane do zewnętrznego adresata, rozstrzygajace indywidualna sprawę administracyjną ${ }^{17}$. W tym też rozumieniu pojęcia „decyzji” będę się posługiwał w dalszym wywodzie. Prawo odwołania przysługuje więc od takiej decyzji, która nie jest ostateczna. Pod pojęciem decyzji ostatecznej należy rozumieć takie decyzje od których nie przysługuje odwołanie w administracyjnym toku instancji ani wniosek o ponowne rozpatrzenie sprawy (definicja legalna $\mathrm{z}$ art. 16 k.p.a.). Dlatego też rozstrzygnięcie odwołania od decyzji, która ma charakter decyzji ostatecznej przez organ administracji publicznej w ramach konkretnego postępowania - stanowi rażące naruszenie prawa i podlega stwierdzeniu nieważności na podstawie art. 156 par. 1 pkt 2 k.p.a. Trafnie wskazał NSA: „Odwołanie jest bowiem środkiem weryfikacji jedynie nieostatecznych decyzji administracyjnych. ${ }^{18}$

${ }_{15}$ H. Knysiak-Sudyka [w:] T. Woś (red.), Postępowanie administracyjne, str. 190-191, wyd. 3 oraz J. Borkowski [w:] B. Adamiak i J. Borkowski (red.), Kodeks postępowania administracyjnego. Komentarz, str. 175-179, Warszawa 2009, wyd. 10 wraz ze źródłami tam wskazanymi czy P. Gołaszewski [w:] R. Hauser, M. Wierzbowski (red.) Kodeks postępowania administracyjnego. Komentarz. Komentarz, s. 148, Warszawa 2015, wyd. 2.

16 Patrz wyrok NSA, sygn. I OSK 755/06, LEX nr 337023 i wyrok NSA, sygn., I SA 1019/99, LEX nr 78926 oraz wyrok WSA, sygn. IV SA/Po 236/16, LEX nr 2110524.

17 T. Woś [w:] T. Woś (red.), Postępowanie administracyjne, str. 374 wyd. 3 podobnie J. Zimmermann, Prawo administracyjne, str. 332, Warszawa 2014, wyd. 6.

18 Wyrok NSA, sygn. I OSK 708/11, LEX nr 1404107. 
W tym miejscu należy postawić pytanie odnośnie do tego, czy prawo do wniesienia odwołania ma charakter publicznego prawa podmiotowego ${ }^{19}$. Odpowiedź twierdząca niewątpliwie przyczyni się do analizy możliwości zrzeczenia się odwołania w kontekście publicznych praw podmiotowych.

Wskazuje się, że o publicznych prawach podmiotowych możemy mówić wówczas, gdy jednostka np. obywatel (...) może żądać określonej reakcji ze strony państwa ${ }^{20}$. Prof. Zimmermann z kolei wskazuje, że publiczne prawa podmiotowe cechuje możliwość samodzielnego wyznaczania obowiązków dla organów administracji publicznej. Raz jeszcze podkreślić należy, że prawa te dotyczą relacji z państwem, a nie z innymi obywatelami. ${ }^{21}$ Przyrównując zaprezentowaną definicję do pokrótce zarysowanego prawa do odwołania, należy stwierdzić, że możemy mówić o prawie do wniesienia odwołania jako o publicznym prawie podmiotowym. Strona bowiem może żądać w określonym postępowaniu administracyjnym załatwienia sprawy (bez zbędnej zwłoki) poprzez merytoryczną kontrolę, w następstwie czego nastąpi wydanie rozstrzygnięcia o treści pozytywnej bądź negatywnej przez organ administracji publicznej (oczywiście o ile ustawa przewiduje kompetencję organu do wydania rozstrzygnięcia $\mathrm{w}$ formie decyzji, a nie dopuszcza np. załatwienia sprawy milcząco). Innymi słowy właściwy organ administracji publicznej będzie adresatem roszczenia strony i będzie zobowiązany do spełnienia obowiązku, którego treść w sposób samodzielny wyznaczyła strona. Na koniec warto wskazać, że możliwość skorzystania z publicznego prawa podmiotowego, jakim jest wniesienie odwołania jest niewątpliwie powiązane w istotny sposób z zasadą dwuinstancyjności postępowania administracyjnego, która jest usytuowana w art. 15 k.p.a ${ }^{22}$.

19 Publiczne prawa podmiotowe stanowią najwęższy element tzw. „Triady Bernatzika”. W skład wspomnianej triady wchodzi również interes prawny oraz interes faktyczny (pojęcie najszersze).H. Knysiak-Sudyka [w:] T. Woś, Postępowanie administracyjne, str. 18, wyd. 3 za: E Bernatzik, Rechtsprechung und materielle Rechtskraft, Wiedeń 1886.

20 J. Boć i A. Błaś [w:] Jan Boć (red.), Prawo administracyjne, str. 307, Wrocław 1993 podobnie M. Stahl [w:] M. Stahl, Prawo administracyjne. Pojęcia, instytucje, zasady w teorii i orzecznictwie, str. 75-77, Warszawa 2009, wyd. 4.

${ }_{21}$ Tak np. W. Jakimowicz, O publicznych prawach podmiotowych, Państwo i Prawo 1999, nr 1, s. 36-50 (dostęp 28.11.2017: http://ftp.czytelniaonline.lex.pl/getpdf/pip/pdf/1999/01/pip_1999 _01_036.pdf?LX03356F00E000350045004300F6 910EDAFC20C100F003B2A80B1A4E1D825A95007E0025001F0035185F00 32000775BB1783004B001C0009000F00840003008800BE00 3D006600).

22 J. Zimmermann, Prawo administracyjne, str. 136, Warszawa 2014, wyd. 6. 


\section{RELACJA MIĘDZY PUBLICZNYM PRAWEM PODMIOTOWYM W PRAWIE ADMINISTRACYJNYM I W PRAWIE KONSTYTUCYJNYM}

Odnosząc się do publicznych prawach podmiotowych w powyższym znaczeniu powstaje pytanie o relację między nimi a koncepcją praw podmiotowych sformułowaną przez doktrynę prawa konstytucyjnego. Zanim zostanie udzielona odpowiedź na sformułowane pytanie, warto pokrótce przedstawić konstytucyjną koncepcję praw podmiotowych. O prawie podmiotowym w rozumieniu konstytucji RP możemy mówić, gdy jednostka znajduje się w takiej sytuacji prawnej, że może żądać określonego podmiotu określonego zachowania (działania albo zaniechania), a tym samym podmiot ten staje się zobowiązany do realizacji konkretnego obowiązku. Ponadto cechuje je możliwość egzekucji tegoż uprawnienia w przypadku braku jego realizacji przez podmiot na którym ciąży obowiązek. ${ }^{23}$ Wniosek o istnieniu praw na poziomie konstytucyjnym, na które można się skutecznie powoływać przed sądami wynika $\mathrm{z}$ odrzucenia poglądu o programowym charakterze konstytucji. ${ }^{24}$ Adresatem konstytucyjnych praw podmiotowych jest przede wszystkim władza publiczna i jej organy, ponieważ prawa te działają przede wszystkim na płaszczyźnie wertykalnej - stąd mowa o publicznych prawach podmiotowych (jako odróżnienie od prywatnych praw podmiotowych ${ }^{25}$ ). Doktryna prawa konstytucyjnego przyjmuje jednak, że prawa podmiotowe mogą funkcjonować także w wymiarze horyzontalnym czyli pomiędzy jednostkami. ${ }^{26}$ Przy czym jest to sytuacja atypowa ${ }^{27}$ - zasadą jest obowiązywanie praw podmiotowych $\mathrm{w}$ stosunku do państwa. ${ }^{28}$ Przykładem takiego prawa jest chociażby prawo do prywatności ${ }^{29}$ (art. 47 Konstytucji i n.), w przypadku którego ochrona jest przyznawana jednostce niezależnie od tego czy podmiotem, który narusza jej prawo jest organ władzy publicznej czy inna

${ }^{23}$ K. Wojtyczek [w:] P. Sarnecki (red.), Prawo konstytucyjne, str. 89 i n., Warszawa 2014, wyd. 9.

${ }_{24}$ P. Tuleja, Stosowanie Konstytucji RP w świetle zasady jej nadrzędności (wybrane problemy), s. 129 i n., Zakamycze 2003.

${ }_{25}$ Ibidem wraz ze wskazanym odesłaniem do autora koncepcji - Georga Jellinka (G. W Jellinek, System der subjektiven öffentlichen Rechte, 1919, s. 54 i n.) https://archive.org/stream/systemdersubjek00jellgoog\#page/n57/mode/2up (dostęp 28.11.2017).

${ }^{26}$ M. Florczak-Wątor, Horyzontalny wymiar praw konstytucyjnych, s. 60-61, Kraków 2014, wyd. 1, choć L. Garlicki dopuszcza jedynie istnienie „pośredniego” efektu horyzontalnego (zob. L. Garlicki, Polskie prawo konstytucyjne. Zarys wyktadu., s. 120-121, Warszawa 2006, wyd. 3).

${ }^{27}$ Aby konstytucyjne prawa i wolności mogły mieć zastosowanie w aspekcie horyzontalnym konieczne jest spełnienie kilku warunków - zob. Ibidem, str. 283-285.

${ }_{28}$ P. Radziewicz [w:]A. Młynarska i P. Radziewicz (red.) Horyzontalne oddziaływanie Konstytucji i Konwencji o ochronie praw człowieka i podstawowych wolności, ,, Studia i Materiały Trybunału Konstytucyjnego", t. 56, s.45-47, Warszawa 2015, (dostęp: 28.11.2017): http://trybunal.gov.pl/ uploads/media/SIM_LVI_calosc.pdf

${ }^{29}$ M. Safjan, L. Bosek (red.), Konstytucja RP. Tom I. Komentarz do art. 1-86, komentarz do art. 47, t. 1, str. 1173, Warszawa 2016. wyd. 1. 
jednostka. Przepisy rangi konstytucyjnej mają tutaj, jednakże zastosowanie tylko w sytuacji gdy przepisy rangi ustawowej (uszczegóławiające określone prawa i wolności) okażą się niewystarczające czyli subsydiarnie. ${ }^{30}$

Przedstawiona w doktrynie prawa administracyjnego koncepcja publicznych praw podmiotowych zdaje się być bardzo podobna do tej, którą sformułowano na gruncie konstytucyjnym. Cechą jednak odróżniająca te dwie definicje jest to, że konstytucyjne prawa podmiotowe mogą (jako odstępstwo od zasad) funkcjonować w relacji horyzontalnej - w przeciwieństwie do praw publicznych podmiotowych $\mathrm{w}$ znaczeniu administracyjnoprawnym ${ }^{31}$. $\mathrm{Z}$ tego też powodu odmienny będzie adresat, z którego zachowaniem skorelowane są żądania określonego podmiotu, który dochodzi realizacji swojego prawa podmiotowego. W przypadku konstytucyjnego prawa podmiotowego może to być zarówno Państwo jak i inne jednostki ${ }^{32}$. Natomiast w przypadku konstrukcji publicznego prawa podmiotowego w znaczeniu administracyjnoprawnym możemy mówić o adresacie, którym jest Państwo (organy władzy publicznej, bądź jeszcze konkretniej - organy administracji publicznej). Pozwala to wysnuć stwierdzenie, że zarysowana koncepcja publicznych praw podmiotowych w znaczeniu administracyjno-prawnym zawiera się w szerszej koncepcji konstytucyjnych praw podmiotowych. Dlatego też, ponieważ przedstawione wcześniej prawo do wniesienia odwołania zostało uznane na gruncie prawa nauki prawa administracyjnego za publiczne prawo podmiotowe, to konsekwentnie należy przyjąć, że będzie ono również konstytucyjnym prawem podmiotowym, którego podstawę możemy dostrzec w art. 78 Konstytucji RP. Możemy więc tutaj mówić o logicznej relacji zawierania się. Za trafne należy zatem uznać stwierdzenie, wedle którego koncepcja publicznych praw podmiotowych z k.p.a. jest węższa w stosunku do koncepcji zawartej między wierszami polskiej konstytucji - została one bowiem, jak trafnie stwierdzono, „okrojona z powodu potrzeby dostosowania ich do potrzeb prawa administracyjnego" 33 . Podobnie jak system prawa administracyjnego (znajdujący się w ustawach oraz innych źródłach prawa sensu largo) znajduje swoje zakorzenienie w treści Konstytucji - tak samo publiczne prawa podmiotowego znajdują swój początek oraz swoją istotę w treści ustawy zasadniczej. Kwestią odmienną jest to czy źródłem wszystkich praw i wolności (rozumianych szeroko - nie tylko jako praw publicznych podmiotowych) jest godność

${ }^{30}$ K. Wojtyczek [w:] P. Sarnecki (red.), Prawo konstytucyjne, str. 92, Warszawa 2014, wyd. 9 oraz M. Florczak-Wątor, Horyzontalny wymiar praw konstytucyjnych, s. 346-347, Kraków 2014, wyd. 1.

${ }^{31}$ Czyli takim, które zostało przedstawione powyżej i jest powszechnie akceptowane i przyjmowane przez doktryna prawa administracyjnego - zob. przedstawione w punkcie 3 definicje Prof. Bocia i Prof. Zimmermanna.

32 W tym przypadku również na państwo są nałożone określone gwarancje w zakresie zapewnienia możliwości wykonywania określonych praw podmiotowych - np. ochrona pokojowych i legalnych zgromadzeń przez funkcjonariuszy Policji.

33 J. Boć i A. Błaś [w:] Jan Boć (red.), Prawo administracyjne, str. 308, Wrocław 1993. 
$\mathrm{Z}$ art. 30 Konstytucji. ${ }^{34} \mathrm{Z}$ tego też względu nie mogą istnieć administracyjnoprawne publiczne prawa podmiotowe, nie będąc jednocześnie konstytucyjnym prawem podmiotowym. Dopuszczalna jest natomiast sytuacja odwrotna - taka w której przysługuje jednostce prawo podmiotowe, natomiast nie będzie ono uznane za publiczne prawo podmiotowe $\mathrm{w}$ znaczeniu powszechnie uznawanym przez doktrynę prawa administracyjnego. Dlatego każde publiczne prawo podmiotowe, bez względu na to czy funkcjonuje ono w systemie prawa publicznego czy prywatnego znajduje swoją podstawę w treści ustawy zasadniczej ${ }^{35}$.

\section{ZRZECZENIE SIĘ PRAWA DO WNIESIENIA ODWOŁANIA W OGÓLNOŚCI}

Zrzeczenie się zostało wprowadzone wspomnianą wcześniej nowelizacją, której głównym postulatem wprowadzonej regulacji była szybkość postępowania i ekonomii procesowej ${ }^{36}$. Ustawodawca dopuścił, że zrzeczenie się przysługuje stronie. Stronę do tegoż uprawnioną należy rozumieć w taki sposób jak stronę, której przysługuje odwołanie (art. 28 k.p.a.). Przy czym zastrzega, że odwołanie musi być „,wobec” organu administracji publicznej, który daną decyzję wydał (przy założeniu, że był to organ ,właściwy”37), a nie jakiegokolwiek z organów administracji publicznej bądź organów państwa. Ustawa stanowi, że oświadczenie staje się skuteczne z chwilą doręczenia - co wskazywać mogłoby na to, że konieczne jest złożenie takiego oświadczenia w formie pisemnej. Również ustawodawca w uzasadnieniu do projektu ustawy wskazuje na wymóg formy pisemnej ${ }^{38}$.

Oświadczenie woli, zgodnie z wolą ustawodawcy, ma skutkować tym, że wydana decyzja uzyskuje przymiot ostateczności - nie służy od nich odwołanie w administracyjnym toku instancji, ani wniosek o ponowne rozpatrzenie sprawy (art. $16 \S 1$ k.p.a.). Ponadto decyzja taka zyskałaby status decyzji prawomocnej - nie przysługiwałaby zatem na nią skarga do sądu administracyjnego ${ }^{39}$ (art. 16 § 3 k.p.a.).

${ }^{34}$ M. Safjan, L. Bosek (red.), Konstytucja RP. Tom I. Komentarz do art. 1-86, komentarz do art. 30, str. 739-741 Warszawa 2016. wyd. 1.

${ }^{35}$ Ustawa z dnia 7 kwietnia 2017 r. o zmianie ustawy - Kodeks postępowania administracyjnego oraz niektórych innych ustaw, (Dz.U. 2017 poz. 935).

${ }^{36}$ Uzasadnienie do rządowego projektu ustawy o zmianie ustawy - Kodeks postępowania administracyjnego oraz niektórych innych ustaw, str. 56-58 (Druk nr 1183) (dostęp: 02.12.2017).

${ }^{37}$ Przy czym na względzie należy mieć chociażby regulację przewidzianą w art. 65 k.p.a.

${ }^{38}$ Uzasadnienie do rządowego projektu ustawy o zmianie ustawy - Kodeks postępowania administracyjnego oraz niektórych innych ustaw, str. 56-58 (Druk nr 1183) (dostęp: 02.12.2017) http:// orka.sejm.gov.pl/Druki8ka.nsf/0/F3388D1AB00B1313C125809D004C3C8E/\%24File/1183.pdf

${ }^{39} \mathrm{~W}$ trybie przewidzianym Ustawą z dnia 30 sierpnia 2002 r. Prawo o postępowaniu przed sądami administracyjnymi. (Dz. U. $2002 \mathrm{nr} 153$ poz. 1270). 


\section{ODWOŁANIE A ZRZECZENIE SIE - RELACJA UPRAWNIEŃ PROCESOWYCH}

Intuicyjny wydaje się wniosek, że skoro prawo do wniesienia odwołania zostało w poprzedniej części artykułu uznane za publiczne prawo podmiotowe, to za jego część należy uznać możliwość zrzeczenia się tego prawa - wydaje się, że jest to czynność skorelowana z możliwością wniesienia odwołania i niejako od niej pochodna. Taki wniosek można przynajmniej wysnuć biorąc pod uwagę wykładnię systemową.

Z kolei patrząc z perspektywy uprawnień procesowych strony, które jej przysługują, to wniesienie odwołania i zrzeczenie się go, wydają się być niezależne, konkurencyjne czy wręcz wykluczające się nawzajem (pomimo zastosowanej przez ustawodawcy redakcji tekstu prawnego). Czysto hipotetycznie i nieco w oderwaniu od kontekstu czy konkretnej regulacji prawnej - nie jest możliwe wniesienie odwołania w przypadku, gdy podmiot uprawniony się go zrzekł. Skorzystanie więc ze zrzeczenia uniemożliwia skorzystanie z odwołania. Natomiast skorzystanie uprzednio z odwołania nie wyklucza możliwości zrzeczenia się go. Dlatego zrzeczenie wydaje się być bardziej brzemienne w skutki - nie tylko neguje poprzednią czynność (wniesienie odwołania), ale także uniemożliwia skorzystanie z niej w przyszłości. Teza o pochodności czy o pewnym uzależnieniu zrzeczenia od wniesienia odwołania zdaje się być nietrafiona. $Z$ tego też względu wydaje się, że prawo do zrzeczenia się odwołania nie jest publicznym prawem podmiotowym tak jak prawo do wniesienia odwołania i należy rozpatrzyć to prawo autonomicznie i niejako w opozycji do publicznego prawa podmiotowego (w znaczeniu konstytucyjnym i administracyjnoprawnym), jakim jest prawo do wniesienia odwołania $\mathrm{z}$ art. 78 ust. 1 Konstytucji oraz art. $127 \S 1$ k.p.a.

\section{ZRZECZENIE SIĘ PUBLICZNYCH PRAW PODMIOTOWYCH (ASPEKT ADMINISTRACYJNY I KONSTYTUCYJNY)}

Na podstawie przedstawionych wcześniej rozważać należy uznać, że zrzeczenie się jest uprawnieniem strony, które powoduje brak możliwości wniesienia odwołania, bądź deroguje możliwość uzyskania go w ramach wszczętego już postępowania w tym zakresie. Ingeruje ono więc w pewien sposób w zakres ochrony ustanowiony przez prawo administracyjne jak i prawo konstytucyjne. Zrzeczenie się prawa do wniesienia odwołania jest więc także zrzeczeniem się publicznych praw podmiotowych w powyższym znaczeniu. W tym miejscu powstaje więc pytanie - czy dopuszczalne jest zrzeczenia się prawa do wniesienia odwołania, rozumianego jako publiczne prawo podmiotowe (oraz tym samym zrzeczenie się możliwości zaskarżenia decyzji przewidziane w ustawie zasadniczej)? 


\section{A) DECYZJA OSTATECZNA}

Ustawodawca wskazał, że jednym ze skutków zrzeczenia się jest uzyskanie przez decyzję przymiotu decyzji ostatecznej, zgodnie z treścią art. 16 k.p.a.

Tym samym powoduje to rezygnację, ale też brak dalszej możliwości do uzyskania - być może - decyzji korygującej, o zupełnie innych skutkach niż decyzja wydana przez organ administracji publicznej w ramach I instancji. Doktryna prawa administracyjnego wskazuje, że - co do zasady - nie jest dopuszczalne zrzeczenie się prawa podmiotowego ${ }^{40}$ (a za takie uznaje się możliwość wniesienia odwołania). Przykładowo prof. Zimmermann wyprowadza taki wniosek z cech interesu prawnego oraz cech publicznych praw podmiotowych (kategorii węższej). ${ }^{41}$ Publiczne prawa podmiotowe są zatem kategoria obiektywną (istnieją obiektywnie) i tylko od podmiotu, któremu przysługują zależy ich realizacja (sfera subiektywna). ${ }^{42}$ Nie ma zatem obowiązku korzystania z tego uprawnienia - tym samym skutek równoważny ze zrzeczeniem się (w zakresie uostatecznienia się decyzji), można uzyskać po prostu przez upływ czasu nieprzerwany żadnym zachowaniem strony przewidzianym w celu zmiany status quo.

Przytoczone wyżej poglądy akcentujące obiektywny charakter publicznych praw podmiotowych zdają się dobrze oddawać zasadę, zgodnie z którą nie jest dopuszczalne zrzeczenie się prawa podmiotowego. Od zasady niezrzekalności się praw podmiotowych przewiduje się także wyjątki - muszą one być jednak wprost i wyraźnie dopuszczalne przez prawo obowiązujące. ${ }^{43}$ Wydaje się, że skoro ustawodawca (art. 78 ust. 2 Konstytucji) dopuszcza wprost taką możliwość, to należy uznać, że jest to dopuszczalne, ale tylko przy spełnieniu określonych warunków (np. z uwzględnieniem art. 31 ust. 3 Konstytucji). Kwestię tę również potwierdził Trybunał Konstytucyjny wskazując, że: „Nie oznacza to jednak, iż ustawodawca ma pełną, niczym nieskrępowaną swobodę w ustalaniu katalogu takich wyjątków (...), nie mogą prowadzić (one) do przekreślenia samej zasady ogólnej”. TK zwrócił także uwagę na fakt, że wyjątki powinny być podyktowane szczególnymi okolicznościami. ${ }^{44}$ Konstytucja wskazuje, że wyjątki od przewidzianego prawa do zaskarżenia (...) musi wskazywać ustawa - takich wyjątków zatem nie można domniemywać. Wydaje mi się, że ustawodawca spełnił powyższy wymóg dokonując omawianej zmiany w treści k.p.a., a uzasadnieniem będzie nie tyle przewidziana w projekcie szybkość czy ekonomią postępowania, ale sama decyzja strony w tym

40 J. Zimmermann, Prawo administracyjne, str. 319, Warszawa 2014, wyd. 6 i Z. Kmieciak, Odwołania w postepowaniu administracyjnym, s. 105, Warszawa 2011 wraz z przytoczonymi tam poglądami I. Wajnesa oraz W. Dawidowicza.

41 J. Zimmermann, Prawo administracyjne, str. 318-319, Warszawa 2014, wyd. 6.

42 J. Boć i A. Błaś [w:] Jan Boć (red.), Prawo administracyjne, str. 308, Wrocław 1993.

${ }_{43}$ Z. Kmieciak, Odwotania w postepowaniu administracyjnym, s. 105, Warszawa 2011 za: I. Wajnes, Ochrona praw i interesów jednostki w postępowaniu administracyjnym, Wilno 1939, s. 115.

${ }_{44}$ Wyrok TK z dnia 12 czerwca 2002 r., sygn. P 13/01, OTK ZU 4A/2002, poz. 42. 
zakresie. Uważam, jednak, że o zrzeczeniu się praw publicznych podmiotowych należy mówić jedynie w kategoriach wyjątku (który powinien występować niezwykle rzadko i być expressis verbis ustanowiony). Nawet jeśli przyjąć, że zrzeczenie się prawa do wniesienia odwołania jest niedopuszczalne, to w istocie - w postępowaniu przed organem administracji publicznej - ze względu na skutki, sytuacja ta nie jest aż tak bardzo różna od przypadku, w którym strona nie wnosi odwołania i upływa termin na skuteczne złożenie go. Ponadto, nawet gdyby uznać, że nie są dopuszczalne wyjątki od zasady niezrzekalności publicznych praw podmiotowych na gruncie prawa administracyjnego, to byłoby to nie tylko de facto zaprzeczenie woli ustawodawcy przewidzianej w art. 78 ust. 2 Konstytucji, ale doprowadzenie do sytuacji, w której odwrócony byłby system źródeł prawa poprzez fakt, że przepisy k.p.a. czy specyficzne ich rozumienie przez doktrynę zaprzeczałyby treści ustawy zasadniczej.

Kontrowersje - przynajmniej na tym etapie analizy - wiążą się również z kwestią skuteczności takiego oświadczenia jak i możliwością cofnięcia go.

Prof. Zimmermann wskazuje, że oświadczenie o zrzeczeniu się publicznego prawa podmiotowego nie wywołuje skutków prawnych ${ }^{45}$. Nie ma zatem ono dla organu administracji publicznej żadnej mocy wiążącej, a tym samym nie umożliwia stronie postępowania, wniesienia odwołania od wydanej decyzji, choć ustrojodawca dopuścił istnienie wyjątków od zasady wyrażonej w treści art. 78 ust. 2 Konstytucji. Rozpatrywanie zatem kwestii cofnięcia oświadczenia nie jest zasadne, skoro Profesor Zimmermann twierdzi, że oświadczenie takie nie jest w ogóle skuteczne. Odmiennie - Prof. Adamiak zdaje się nie kwestionować dopuszczalności złożenia odwołania jak i skuteczności jego cofnięcia (na zasadach ogólnych z kodeksu cywilnego), akcentując przede wszystkim zasadę rozporządzalności ${ }^{46}$. Od woli strony ma bowiem zależeć to czy jej roszczenie będzie dochodzone ${ }^{47}$. Pogląd prof. Zimmermanna zdaje się nie uwzględniać przewidzianego powyżej wyjątku. Powtórzyć raz jeszcze należy, że ustawodawca wprost dopuścił taki wyjątek i ani przepisy prawa administracyjnego ani wyinterpretowane z nich treści przy pomocy wykładni prawniczej nie mogą negować tekstu ustawy zasadniczej. Dlatego też doktryna prawa konstytucyjnego zdaje się dopuszczać regulacje ustawowe, które

45 J. Zimmermann, Prawo administracyjne, str. 318-319, Warszawa 2014, wyd. 6 oraz Tenże, Kilka refleksji o nowelizacji kodeksu postępowania administracyjnego, str. 15-16, „Państwo i Prawo" 2018, nr 8, (dostęp: 03.12.2017),http://ftp.czytelniaonline.lex.pl/getpdf/pip/pdf/2017/08/ pip_2017_08_003.pdf?LX03356F00E000350045004300F64C0F75262 0C100F003B2F60B8B4E19825A95007E0025001F0035185F0032000775BB1783004 B001C0009000F00840003008800BE 003D006600).

${ }^{46} \mathrm{O}$ granicach zasady rozporządzalności - zob. B. Adamiak [w:] R. Hauser, Z. Niewiadomski, A. Wróbel (red.), System prawa administracyjnego, t. 9, s. 161-165, Warszawa 2017, wyd. 3.

${ }^{47}$ B. Adamiak [w:] B. Adamiak i J. Borkowski (red.), Kodeks postępowania administracyjnego. Komentarz, str. 465, Warszawa 2009, wyd. 10. 
mogą ograniczać konstytucyjne prawo podmiotowe do zaskarżenia, jednocześnie wskazując, że prawo to nie ma charakteru absolutnego ${ }^{48}$.

Tym samym, sądzę, że jeśli konstrukcja zrzeczenia się prawa do wniesienia jest dopuszczalna na gruncie polskiego postępowania administracyjnego, w zakresie dotyczącym postępowania przed organami administracji publicznej - co starałem się wyżej przedstawić i udowodnić - to powstaje pytanie o sens danej regulacji. Nie ulega bowiem wątpliwości, że termin na wniesienie odwołania wynosi 14 dni, a oświadczenie o zrzeczeniu się go „zaoszczędzi” organowi aż (sic!) kilku dni. W zasadzie skutek, patrząc z perspektywy jednostki, zostałby również osiągnięty, gdyby jednostka zdecydowała się nie dochodzić określonego uprawnienia i upłynąłby termin do złożenia odwołania. $Z$ tego też względu wydaje się, że regulacja ta wydaje się być jedynie pozornie korzystnym udogodnieniem dla obywatela, a de facto ma ona służyć głównie organom administracji publicznej. Budzi to wątpliwości z perspektywy zasadności stanowienia prawa dla obywateli (prawo administracyjne jako prawo obywatelskie $)^{49}$.

Ustawodawca w projekcie ustawy ${ }^{50}$ nie wskazał dodatkowych zalety danej regulacji - zdaje się, że głównym atutem jest szybkość postępowania i ekonomia procesowa. Uprawnienie do zrzeczenia się nie wpływa w sposób istotny na sytuację prawną strony niezainteresowanej swoimi interesami, która i tak nie dochodziłaby swoich roszczeń - wydaje się więc, że regulacja ta nie miała charakteru rewolucyjnego ani koniecznego. $Z$ tego też względu sądzę, że w zakresie przedstawionym jest ono zbyteczna, a korzyści, które przewiduje dotyczą tylko jednej strony stosunku administracyjnoprawnego ${ }^{51}$, czyli organu. Zatem, o ile wydaje mi się, że dopuszczalne jest istnienie przedstawionej konstrukcji na gruncie teoretycznym, o tyle jego zasadność, praktyczne zastosowanie oraz budzą wątpliwości.

\section{B) DECYZJA PRAWOMOCNA}

Dostrzegalnym problemem powstającym na tle wprowadzonej regulacji jest również kwestia prawomocności. Zrzeczenie się bowiem - w intencji ustawodawcy - powoduje nie tylko brak możliwości wniesienia odwołania, ale także brak możliwości wniesienia skargi do sądu administracyjnego. Krytycznie należy

${ }^{48}$ P. Grzegorczyk i K. Weitz [w:] M. Safjan, L. Bosek (red.), Konstytucja RP. Tom I. Komentarz do art. 1-86, komentarz do art. 78, str. 1788, Warszawa 2016. wyd. 1 wraz odesłaniem tam przytoczonym oraz podanym przykładem zrzeczenia się możliwości wniesienia apelacji w postępowaniu uproszczonym w k.p.c.

49 J. Zimmermann, Prawo administracyjne, str. 47 i 119, Warszawa 2014, wyd. 6.

${ }^{50}$ Ustawa z dnia 7 kwietnia 2017 r. o zmianie ustawy - Kodeks postępowania administracyjnego oraz niektórych innych ustaw, (Dz.U. 2017 poz. 935).

${ }^{51}$ Odnośnie pojęcia „stosunku administracyjnoprawnego” - Patrz J. Starościak [w:] System prawa administracyjnego, T. Rabska i J. Łętowski (red.), t. 3, s. 5-39, Wrocław 1978 lub E. Ochendowski, Prawo administracyjne. Część ogólna., s. 37-41, Toruń 2002, wyd. 5. 
ocenić brak w uzasadnieniu kwestii odniesienia się do art. 45 ust. 1 Konstytucji. ${ }^{52}$ Ustawodawca odniósł się jedynie do treści art. 78 ust. 1, natomiast milczy w kwestii art. 45 ust. 1 Konstytucji (wraz z treścią art. 77 ust. 2 K.). Prof. Adamiak trafnie dostrzega, że ,znaczenie prawa procesowego dla wyznaczenia granic prawa do procesu nie może podważać roli i znaczenia (...) regulacji przyjętej w Konstytucji RP". Ponadto, doktryna prawa konstytucyjnego przewiduje, że choć konstytucyjne prawa podmiotowe $\mathrm{z}$ art. $78 \mathrm{i}$ art. 45 są ze sobą powiązywalne, to jednak każde z nich ma też samodzielną i autonomiczną treść (wartość) $)^{53}$. Na tle przedstawionej sytuacji wydaje się, że postawienie pytania o naruszenie prawa do sądu (art. 45 ust.1 Konstytucji) jest jak najbardziej zasadne.

Wspomniany artykuł statuuje jedna z najważniejszych zasad polskiego prawa, a zarazem publiczne prawo podmiotowe ${ }^{54}$, którego treścią jest prawo do sądu. Artykuł ten przewiduje szereg gwarancji procesowych ${ }^{55}$ dla jednostki, które mają prewencyjnie wyeliminować potencjalne różnicowanie sytuacji podmiotów w sposób, który narusza zasadę równości (art. 32 Konstytucji). Prawo do sądu, podobnie jak prawo do zaskarżenia decyzji nie ma charakteru absolutnego - na co wskazywał TK - wiążąc to, chociażby z ograniczeniami w postaci rygoru postępowania dowodowego. Wskazane jednak ograniczenia są uzasadniane innymi zasadami (wartościami) takimi jak np. pewność prawa czy zaufanie obywateli do państwa ${ }^{56}$ (elementy składowe meta-zasady demokratycznego państwa prawnego). Ograniczenia te jednak są zupełnie inne niż ograniczenie przewidziane w treści art. 78 ust. 2 ustawy zasadniczej. Mają one bowiem mniej doniosły charakter i nie umożliwiają dochodzenia swoich praw, lecz jedynie je ograniczają. Z kolei wyjątki, które przewidział ustawodawca w stosunku do prawa zaskarżania decyzji czy orzeczeń, mogą nie tylko utrudniać dochodzenie swoich praw, ale w wyjątkowych sytuacjach także to uniemożliwiać. $Z$ tego też względu standard badania naruszenia prawa (do sądu)

${ }^{52}$ Uzasadnienie do rządowego projektu ustawy o zmianie ustawy - Kodeks postępowania administracyjnego oraz niektórych innych ustaw, str. 56-58 (Druk nr 1183) (dostęp: 04.12.2017) http:// orka.sejm.gov.pl/Druki8ka.nsf/0/F3388D1AB00B1313C125809D004C3C8E/\%24File/1183.pdf

${ }_{53}$ Postanowienie SN z dnia 21 maja 2002 r. III CK 53/02, LEX nr 55849 lub L. Garlicki i K. Wojtyczek [w:] Konstytucja Rzeczypospolitej Polskiej. Komentarz do art. 30-86, t. 2, str. 876-877, Warszawa 2016, wyd. 2 wraz z orzecznictwem tam przytoczonym czy P. Grzegorczyk i K. Weitz [w:] M. Safjan, L. Bosek (red.), Konstytucja RP. Tom I. Komentarz do art. 1-86, komentarz do art. 45, str. 1094-1095, Warszawa 2016. wyd. 1.

${ }_{54}$ Postanowienie SN z dnia 21 maja 2002 r. III CK 53/02, LEX nr 55849 oraz Joanna Człowiekowska, Prawo do sądu jako publiczne prawo podmiotowe, ZNUJ 2006/5/175-184, (dostęp: 04.12.2017) http://www.lex.pl/akt/-/akt/prawo-do-sadu-jako-publiczne-prawo-podmiotowe i P. Grzegorczyk i K. Weitz w: M. Safjan, L. Bosek (red.), Konstytucja RP. Tom I. Komentarz do art. 1-86, komentarz do art. 45, str. 1096-1097, Warszawa 2016. wyd. 1.

${ }_{55}$ Przykładowo: Wyrok TK z dnia 9 czerwca 1998 r., K 28/97, OTK 1998, nr 4, poz. 50.

56 Wyrok TK z dnia 10 maja 2000 r., K 21/99, OTK 2000, nr 4, poz. 109. 
będzie - w moim odczuciu - znacznie wyższy, w przypadku, gdy wzorcem kontroli będzie konstytucyjne prawo podmiotowe umieszczone w art. 45 ust. 1 Konstytucji.

Powstaje pytanie czy zrzeczenie się prawa do wniesienia odwołania, które w konsekwencji uzyskuje przymiot decyzji prawomocnej nie stanowi naruszenia konstytucyjnego prawa podmiotowego, jakim jest prawo do sądu. Bowiem jak twierdzi prof. Adamiak: ,znaczenie prawa procesowego dla wyznaczenia granic prawa do procesu nie może podważać roli i znaczenia (...) regulacji przyjętej w Konstytucji RP" 57 .

Kontrą do postawionej tezy może być odpowiedź, że skoro strona zrzekła się możliwości do wniesienia odwołania, to tym bardziej nie będzie chciała dochodzić tego przed sądem administracyjnym - zapewne takie było też przekonanie prawodawcy. W replice należy jednak wskazać, że może istnieć sytuacja, w której strona, wie, że jej sprawa nie zostanie rozstrzygnięta w inny sposób niż w I instancji (ze względu na wadliwości w funkcjonowaniu organu bądź jego pracowników ${ }^{58}$ ). We wskazanej sytuacji uprawnienie do zrzeczenia się nabiera przymiotu korzystności dla strony - może ona bowiem z pominięciem odwołania złożyć skargę do sądu administracyjnego, a tym samym rzeczywiście zaoszczędzi trochę czasu w dochodzeniu swojego roszczenia. Zapatrywanie to jest mało idealistyczne, a przedstawiony sposób spojrzenia na funkcjonowanie polskich organów administracji publicznej jest być może daleki od rzeczywistości. Z tego też względu zasadne wydaje się rozróżnienie sfery ostateczności i sfery prawomocności.

Sfera prawomocności - jak już wskazałem - oddziałuje na treść prawa do sądu, które niewątpliwie jest konstytucyjnym prawem podmiotowym. Zrzeczenie się prawa do wniesienia odwołania powoduje brak możliwości dochodzenia swojego roszczenia przed sądem administracyjnym, a przecież można wyobrazić sobie stany faktyczne, w których pomimo uprzedniego zrzeczenia się, możliwość wniesienia skargi do sądu administracyjnego może stać się pożądana. Tym samym zrzeczenie się niejako przekreśla i uniemożliwia skorzystanie z konstytucyjnego uprawnienia - wydaje mi się, że ustrojodawca nie dopuścił od tej zasady wyjątków, które w tak istotny sposób mogłyby ingerować w sferę podstawowych praw i wolności, już nie tylko obywatela, ale również człowieka ${ }^{59}$. Prowadzi to do sytuacji, w której ustawodawca modyfikuje treść ustawy zasadniczej w sposób z nią sprzeczny i najprawdopodobniej odrzucający wolę i intencje ustrojodawcy. Tym samym stwarza też dalsze pole do nadużyć i powoduje, że sfera podstawowych

${ }^{57}$ B. Adamiak [w:] R. Hauser, Z. Niewiadomski, A. Wróbel (red.), System prawa administracyjnego, t. 9, s. 109, Warszawa 2017, wyd. 3.

${ }^{58}$ Przy założeniu, że nie będzie możliwe wyłączenie ani organu ani jego pracownika w trybie przewidzianym przepisami k.p.a..

${ }_{59}$ Art. 6 Konwencji o Ochronie Praw Człowieka i Podstawowych Wolności sporządzona w Rzymie dnia 4 listopada 1950 r., zmieniona następnie Protokołami nr 3, 5 i 8 oraz uzupełniona Protokołem nr 2., (Dz.U. 1993 nr 61 poz. 284). 
praw obywatela i człowieka mogłaby ulegać systematycznemu zawężeniu, poprzez działania władzy ustawodawczej. Powoduje to również w aspekcie indywidualnym uniemożliwienie konkretnej jednostce dochodzenia swoich roszczeń przed sądem administracyjnym np. na skutek nieprzemyślanego zrzeczenia się tegoż uprawnienia. Dlatego też należy przyznać, że omawiana regulacja w części uniemożliwiającej możliwość wniesienia skargi do sądu administracyjnego od uzyskanej decyzji być może narusza konstytucyjnego prawa do sądu (a być może nawet jego istotę), które umiejscowione jest w treści art. 45 ust. 1 Konstytucji. Powołana w projekcie nowelizacji szybkość czy ekonomia postępowania nie może być na tyle istotnym argumentem, żeby uniemożliwiać stronie postępowania późniejsze dochodzenie swoich praw przed sądem administracyjnym.

\section{PODSUMOWANIE}

Przedstawione wyżej rozważania zdają się prowadzić do wniosku, że wprowadzona do kodeksu postępowania administracyjnego możliwość zrzeczenia się prawa do złożenia odwołania jest instytucją daleko idącą w skutki. Możliwość zrzeczenia się prawa do wniesienia odwołania uniemożliwiłaby jednostce wniesienie odwołania (ostateczność) i wniesienie skargi do sądu administracyjnego (prawomocność). Motywem ustawodawcy była chęć przyśpieszenia postępowań oraz ekonomia procesowa. O ile należy ocenić, że wszelkie próby, które mają przyśpieszyć rozstrzyganie indywidualnych spraw przed organami administracji publicznej są słuszne i jak najbardziej zasługują na aprobatę, o tyle takie, które mogą powodować naruszenie podstawowych praw i wolności człowieka - jakimi są konstytucyjne prawa podmiotowe do zaskarżenia czy do sądu - należy ocenić w sposób negatywny.

Szybkość postępowania nie może być wartością istotniejszą niż prawo do sądu, które stanowi podstawową zasadę i dorobek polskiego konstytucjonalizmu. Przewidziana możliwość zrzeczenia się prawa do wniesienia odwołania, zdaje się naruszać treść tej normy, jednakże kompetencja do definitywnej odpowiedzi na to pytanie przysługuje Trybunałowi Konstytucyjnemu. Niestety ustawodawca nie dostrzegł w treści uzasadnienia ${ }^{60}$ problemu jaki może budzić kwestia prawomocności z perspektywy prawa konstytucyjnego.

Z kolei ustrojodawca dopuścił istnienie wyjątków od konstytucyjnego prawa podmiotowego jakim jest prawo do zaskarżania decyzji i orzeczeń - zatem standard rygoryzmu oceny będzie niższy. $Z$ tego też względu, sądzę, że - w tym zakresie

${ }^{60}$ Uzasadnienie do rządowego projektu ustawy o zmianie ustawy - Kodeks postępowania administracyjnego oraz niektórych innych ustaw, str. 56-58 (Druk nr 1183) (dostęp: 01.12.2017) http:// orka.sejm.gov.pl/Druki8ka.nsf/0/F3388D1AB00B1313C125809D004C3C8E/\%24File/1183.pdf. 
i na gruncie teoretycznym - dopuszczalna jest wspomniana instytucja zrzeczenia się. Jednakże wątpliwości budzi nieco powierzchowne uzasadnienie (zwłaszcza z perspektywy dobrej i starannej legislacji) oraz pozorność zapewnienia jednostce uprawnienia. Podkreślić raz jeszcze należy, że strona niezainteresowana wniesieniem odwołania, nie wniesie go. Dlatego też wątpliwy jest sens istnienia tej instytucji w praktycznym wymiarze.

Podsumowując, uważam, że strona, która będąc adresatem decyzji prawomocnej z powodu zrzeczenia się prawa do wniesienia odwołania może zostać w wyniku własnych nieprzemyślanych działań (bądź braku odpowiedniej znajomości prawa i skutków takowej decyzji), pozbawiona elementarnego i podstawowego prawa człowieka, co jest rozwiązaniem zbyt daleko idącym skutki. $Z$ tego też względu regulacja ta, we wskazanym zakresie nie powinna wywoływać takich skutków i należy ją ocenić krytycznie. Czym innym jest kwestia ostateczności - która o ile wydaje się być bardziej zrozumiałą i mniej rygorystyczną - to jednak należy wskazać, że ustawodawca powinien przyłożyć większą uwagę do wprowadzanej regulacji. Szybkość czy ekonomia postępowania nie jest wartością nadrzędną ani nie powinna być wartością samą w sobie ${ }^{61}$. Interes organu administracji publicznej (zasadzie to on jest beneficjentem wprowadzonej regulacji), polegający na sprawności postępowania nie może bowiem zostać uznany in abstracto za ważniejszy od interesów strony postępowania (jednostki) ${ }^{62}$, nawet jeśli nie chce ona dochodzić swoich roszczeń i w konsekwencji zrzeka się prawa do wniesienia odwołania.

\section{BIBLIOGRAFIA}

Adamiak B, Borkowski J (red.), Kodeks postępowania administracyjnego. Komentarz, Warszawa 2009 Bernatzik E., Rechtsprechung und materielle Rechtskraft, Wiedeń 1886

Boć J. (red.), Konstytucje Rzeczypospolitej oraz komentarz do Konstytucji RP z 1997 roku, Wrocław 1998

Boć J.(red.), Prawo administracyjne, Wrocław 1993

Bosek L., Safjan M. (red.), Konstytucja RP, Warszawa 2016

Człowiekowska J., Prawo do sądu jako publiczne prawo podmiotowe, ZNUJ 2006/5/175-184,

Florczak-Wątor M., Horyzontalny wymiar praw konstytucyjnych, Kraków 2014

Garlicki L., Polskie prawo konstytucyjne. Zarys wyktadu, Warszawa 2006,

Garlicki L., Zubik M., (red.), Konstytucja Rzeczypospolitej Polskiej, Warszawa 2016

Hauser R., Niewiadomski Z., Wróbel A. (red.), System prawa administracyjnego, Warszawa 2017

Hauser R., Wierzbowski M. (red.), Kodeks postepowania administracyjnego. Komentarz., Warszawa 2015

Horyzontalne oddziaływanie Konstytucji i Konwencji o ochronie praw czlowieka i podstawowych wolności, $A$.

${ }^{61}$ J. Zimmermann, Prawo administracyjne, str. 126, Warszawa 2014, wyd. 6.

${ }^{62}$ Dla przykładu - wyrok SN z dnia 18 listopada 1993 r., sygn. III ARN 49/93, LEX nr 9595. 
http://orka.sejm.gov.pl/Druki8ka.nsf/0/F3388D1AB00B1313C125809D004C3C8E/\%24File/1183. pdf (dostęp: 01.12.2017)

http://www.lex.pl/akt/-/akt/prawo-do-sadu-jako-publiczne-prawo-podmiotowe

Jakimowicz W., O publicznych prawach podmiotowych, „Państwo i Prawo” 1999, nr 1,

Jellinek G. W., System der subjektiven öffentlichen Rechte, 1919

Kmieciak Z., Instancyjność postępowania administracyjnego w świetle Konstytucji RP, „Państwo i Prawo" 2012, nr 5

Kmieciak Z., Odwołania w postępowaniu administracyjnym, Warszawa 2011

Konwencja o Ochronie Praw Człowieka i Podstawowych Wolności (Dz.U. 1993 nr 61 poz. 284).

Łętowski J, Rabska T. (red.), System prawa administracyjnego, Wrocław 1978

Młynarska i P. Radziewicz (red.), http://trybunal.gov.pl/uploads/media/SIM_LVI_calosc.pdf(dostęp: 28.11.2017):

Ochendowski E., Prawo administracyjne. Część ogólna, Toruń 2002

Postanowienie SN z dnia 21 maja 2002 r. III CK 53/02, LEX nr 55849

Raport zespolu eksperckiego, Reforma prawa o postępowaniu administracyjnym, http://www.nsa. gov.pl/wydarzenia-wizyty-konferencje/raport-ekspercki-nt-reforma-prawa-o-postepowaniu-administracyjnym,news,24,313.php (dostęp: 07.12.2017)

Sarnecki P. (red.), Prawo konstytucyjne, Warszawa 2014

Skrzydło W., Konstytucja Rzeczypospolitej Polskiej. Komentarz, Zakamycze 2000

Stahl M. (red.), Prawo administracyjne. Pojęcia, instytucje, zasady w teorii i orzecznictwie, Warszawa 2009

Tuleja P., Stosowanie Konstytucji RP w świetle zasady jej nadrzędności (wybrane problemy), Zakamycze 2003

Ustawa z dnia 30 sierpnia 2002 r. Prawo o postępowaniu przed sądami administracyjnymi. (Dz. U. $2002 \mathrm{nr} 153$ poz. 1270).

Ustawa z dnia 7 kwietnia 2017 r. o zmianie ustawy - Kodeks postępowania administracyjnego oraz niektórych innych ustaw (Dz.U. 2017 poz. 935).

Uzasadnienie do rządowego projektu ustawy o zmianie ustawy - Kodeks postępowania administracyjnego oraz niektórych innych ustaw, (Druk nr 1183)

Wajnes I., Ochrona praw i interesów jednostki w postępowaniu administracyjnym, Wilno 1939

Woś T.(red.), Postepowanie administracyjne, Warszawa 2017

Wyrok NSA, sygn. I OSK 708/11, LEX nr 1404107.

Wyrok NSA, sygn. I OSK 755/06, LEX nr 337023

Wyrok NSA, sygn. I SA 1019/99, LEX nr 78926

Wyrok SN z dnia 18 listopada 1993 r., sygn. III ARN 49/93, LEX nr 9595.

Wyrok TK z dnia 10 maja 2000 r., K 21/99, OTK 2000, nr 4, poz. 109

Wyrok TK z dnia 12 czerwca 2002 r., sygn. P 13/01, OTK ZU 4A/2002, poz. 42.

Wyrok TK z dnia 14 czerwca 2006 r., sygn. K 53/05, OTK ZU nr 6/A/2006, poz. 66

Wyrok TK z dnia 15 grudnia 2008, sygn. P 57/07 OTK-A 2008, nr 10, poz. 178.

Wyrok TK z dnia 16 listopada 1999 r., sygn. SK 11/90, OTK ZU 7/1999, poz. 158

Wyrok TK z dnia 9 czerwca 1998 r., K 28/97, OTK 1998, nr 4, poz. 50

Wyrok WSA, sygn. IV SA/Po 236/16, LEX nr 2110524

Zimmermann J., Kilka refleksji o nowelizacji kodeksu postępowania administracyjnego, „Państwo i Prawo" 2018, nr 8

Zimmermann J., Prawo administracyjne, Warszawa 2014

Konstytucja Rzeczypospolitej Polskiej z dnia 2 kwietnia 1997 r. (Dz.U. 1997 nr 78 poz. 483) Ustawa z dnia 14 czerwca 1960 r. Kodeks postępowania administracyjnego (Dz.U. 1960 nr 30 poz. 168). 
Pobrane z czasopisma Studenckie Zeszyty Naukowe http://szn.umcs.pl

Data: 26/04/2023 14:10:03

Możliwość zrzeczenia się prawa do wniesienia odwołania w Kodeksie postępowania...

\section{SUMMARY}

The article is about recent amendment to the Administrative Procedure Code. Recent changes allowed parties to waive the possibility to rescind the decision. The aim of the regulation was to make the proceedings faster and cheaper. As good as it sounds, amendment seems questionable, especially when it comes to constitutional/administrative ,public legal rights” (Polish construction) and basic human rights and freedoms such as a right to a fair trial (article 6 of European Convention on Human Rights). The legislator did not notice that the amendment may violate aforementioned rights and that is why, in this article I will try to judge this amendment basing mainly on principles of Polish Constitution.

Key words: waiver, rescind, decision, amendment, administrative procedure code, polish constitution, a right to a fair trial, 